\title{
Tables and box
}

2.1 Main provisions of the Dodd-Frank Act and their primary aims

2.2 Market capitalization of some leading international banks, 2007 and 2009

2.3 Leverage of financial and non-financial enterprises, 1995-2007

2.4 Financial leverage and write-downs of selected LCFIs

3.1 Summary of explanatory factors for US current account deficit

3.2 Global saving and investment, 1984-2011

3.3 Foreign holdings of US securities, 2002-10 (in billions of US dollars)

4.1 Central bank policy rates, May 2013

4.2 Balance-sheet assets of major central banks, 2007-12 (percentages of gross domestic product)

4.3 Changes in bank reserves, broad money and bank lending, June 2008-June 2009

5.1 World GDP growth, 2003-13 (year-on-year percentage changes)

5.2 Gross government debt to GDP for selected countries, 2007-10

5.3 Shares of world GDP on PPP basis, 2010 and 2017 (per cent of total)

5.4 List of acronyms for groups of emerging market economies

5.5 Contribution to world GDP growth (as a per cent of total), 2003-13

5.6 Top 15 economies in 2050

6.2 Military forces in the Pacific: China and the United States

6.3 The ownership status of Chinese industrial enterprises, 2011

6.4 SOE share of China's GDP, 2007

6.5 Shareholdings of Central Huijin Investment Ltd and

Ministry of Finance in five large Chinese commercial banks, as at 31 December 2010

7.1 Composition of US foreign assets, end 2011 
7.2 Composition of US foreign liabilities, end 2011

7.3 Rates of return on foreign and US cross-border direct and portfolio investments, 1976-2011 188

7.4 US dollar asset and trade weights compared, 2005 192

7.5 Components of changes in the net international investment position, 1989-2011 194

8.1 The state of the union, 2012

8.2 Major renminbi business initiatives, 2003-12 224

9.1 A summary of the main themes in the volume 240

\section{BOX}

8.1 Features of an international currency 232 